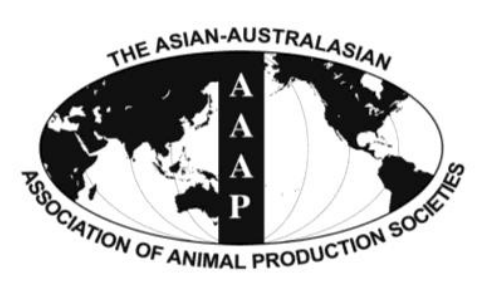

Open Access

Asian Australas. J. Anim. Sci.

Vol. 28, No. 3 : 360-368 March 2015

http://dx.doi.org/10.5713/ajas.14.0346

www.ajas.info

pISSN 1011-2367 elSSN 1976-5517

\title{
Ad libitum Pasture Feeding in Late Pregnancy Does Not Improve the Performance of Twin-bearing Ewes and Their Lambs
}

\author{
R. A. Corner-Thomas*, P. J. Back, P. R. Kenyon, R. E. Hickson, A. L. Ridler, K. J. Stafford, and S. T. Morris \\ Sheep Research Centre, Institute of Veterinary, Animal and Biomedical Sciences, \\ Massey University, Palmerston North 4442, New Zealand
}

\begin{abstract}
The present study evaluated the effect of controlled ryegrass-white clover herbage availability from day 128 until day 142 of pregnancy in comparison to unrestricted availability, on the performance of twin-bearing ewes of varying body condition score (BCS; 2.0, 2.5, or 3.0) and their lambs. It was hypothesised that under conditions of controlled herbage availability, the performance of lambs born to ewes with a greater BCS would be greater than those born to ewes with a lower BCS. During the period that the nutritional regimens were imposed, the pre- and post-grazing herbage masses of the Control regimen $(1,070 \pm 69$ and $801 \pm 30 \mathrm{~kg}$ dry matter $[\mathrm{DM}] / \mathrm{ha}$ ) were lower than the ad libitum regimen $(1,784 \pm 69$ and $1,333 \pm 33 \mathrm{~kg} \mathrm{DM} / \mathrm{ha} ; \mathrm{p}<0.05)$. The average herbage masses during lactation were $1,410 \pm 31 \mathrm{~kg} \mathrm{DM} / \mathrm{ha}$. Nutritional regimen had no effect on ewe live weight, BCS and back fat depth or on lamb live weight, indices of colostrum uptake, maximal heat production, total litter weight weaned or survival to weaning ( $p>0.05$ ). The difference in ewe BCSs and back fats observed among body condition groups was maintained throughout pregnancy ( $\mathrm{p}<0.05)$. At weaning, ewes from the BCS2.0 group had lower BCS and live weight $(2.4 \pm 0.2,74.3 \pm 2.6 \mathrm{~kg})$ than both the BCS2.5 $(2.6 \pm 0.2,78.6 \pm 2.4$ $\mathrm{kg}$ ) and BCS3.0 ewes $(2.7 \pm 0.2,79.0 \pm 2.6 \mathrm{~kg}$; $\mathrm{p}<0.05)$, which did not differ $(\mathrm{p}>0.05)$. Ewe BCS group had no effect on lamb live weight at birth or weaning or on maximal heat production $(\mathrm{p}>0.05)$. Serum gamma glutamyl transferase concentrations of lambs born to BCS3.0 ewes were higher within 36 hours of birth than lambs born to BCS2.0 ewes and BCS2.5 ewes $(51.8 \pm 1.9$ vs $46.5 \pm 1.9$ and $45.6 \pm 1.9 \mathrm{IU} / \mathrm{mL}$, respectively $[\mathrm{p}<0.05])$. There was, however, no effect of ewe body condition on lamb plasma glucose concentration ( $>0.05$ ). Lamb survival was the only lamb parameter that showed an interaction between ewe nutritional regimen and ewe BCS whereby survival of lambs born to BCS2.5 and BCS3.0 ewes differed but only within the Control nutritional regimen ewes (p<0.05). These results indicate farmers can provide twin-bearing ewes with pre- and post-grazing ryegrass-white clover herbage covers of approximately 1,100 and $800 \mathrm{~kg} \mathrm{DM} / \mathrm{ha}$ in late pregnancy, provided that herbage covers are 1400 in lactation, without affecting lamb performance to weaning. The present results also indicate that under these grazing conditions, there is little difference in ewe performance within the BCS range of 2.0 to 3.0 and therefore they do not need to be managed separately. (Key Words: Body Condition Score, Feeding, Back Fat Depth, Live Weight, Survival)
\end{abstract}

\section{INTRODUCTION}

With the increase in the number of lambs weaned per ewe bred in New Zealand over the last 20 years (Statistics New Zealand, 2013) twin born lambs are now a common occurrence. In New Zealand, lambing often coincides with early spring, thereby resulting in the late pregnancy period occurring during winter, when the growth of ryegrass-white

\footnotetext{
* Corresponding Author: R. A. Corner-Thomas. Tel: +64-6-3569099 (85179), E-mail: R.Corner@ massey.ac.nz

Submitted May 12, 2014; Revised Jul. 22, 2014; Accepted Aug. 29, 2014
}

clover pasture is often slow resulting in limited pasture availability (Matthews et al., 2000). To address this limitation, a considerable amount of research has been undertaken to identify the level of restricted feeding of ryegrass-white clover pastures that twin-bearing ewes can tolerate in mid- to late-pregnancy before their performance, and that of their offspring, are negatively affected (Morris and Kenyon, 2004; Corner et al., 2008; Kenyon et al., 2011). Collectively, these studies have shown that twin-bearing ewes can be offered restricted grazing conditions of preand post-grazing masses of approximately 1,200 and $800 \mathrm{~kg}$ 
dry matter (DM)/ha until at least day 136 of pregnancy, followed by ad-libitum feeding levels in late pregnancy and lactation. Under these conditions, pasture intake is controlled during the winter period with no negative effects on either ewe or lamb performance. The potential impact of extending this level of grazing restriction to even later in pregnancy is unknown. It can be postulated that in very late pregnancy twin bearing ewes may fail to physically consume sufficient herbage to meet their nutritional requirements (Nicol and Brookes, 2007) when offered a ryegrass-white clover herbage due to rumen volume restriction as the conceptus increases in size (Forbes, 1968). Further, Everts (1990) reported that multiple-bearing ewe intakes can actually be reduced in late pregnancy. Combined, these studies indicate that there may be little advantage in offering high levels of ryegrass-white clover herbage in late pregnancy.

Body condition score (BCS) is a subjective measure of the body reserves of sheep (Jefferies et al., 1961; Kenyon et al., 2014). Ewe BCS has been reported to positively influence ewe lactation performance and the survival and growth of lambs to weaning (Hossamo et al., 1986; EverettHincks and Dodds, 2009; Thompson et al., 2011). Under situations where the intake of the ewe is below its theoretical nutritional requirements, it may be expected that ewes with greater BCS would be better able to buffer against the nutritional shortfall and achieve better performance than ewes with lesser BCS. The potential interaction between late-pregnancy nutritional level and BCS has not been evaluated in twin-bearing ewes.

Therefore, the present study evaluated the effect of controlled (restricted) ryegrass-white clover herbage availability from day 128 until day 142 of pregnancy in comparison to unrestricted availability to ewes of varying BCS. It was hypothesised, firstly that the performance to weaning of lambs born to ewes offered controlled (restricted) nutritional levels to day 142 would be lower than those born to unrestricted ewes. Secondly, under conditions of controlled nutritional availability the performance of lambs born to ewes with greater BCS would be higher than those born to ewes of lower BCS.

\section{MATERIALS AND METHODS}

\section{Study design}

Eighty-five days (P85) after the start of the breeding period, 200 mixed aged ( 3 to 5 years) twin-bearing Romney ewes were selected from a commercial flock after pregnancy diagnosis. Breeding began on 14 Apr. 2011 (P0). Following pregnancy diagnosis, ewes were selected for the study based on their BCS (BCS2.0 $n=67$, BCS2.5 $n=67$, BCS3.0 $\mathrm{n}=66$ ). Selected ewes had an average live weight of $74.8 \pm 0.5 \mathrm{~kg}$ which differed between each BCS group
$(\mathrm{BCS} 2.0=71.0 \pm 0.9, \quad \mathrm{BCS} 2.5=76.1 \pm 0.9, \quad \mathrm{BCS} 3.0=$ $77.4 \pm 0.9 \mathrm{~kg} ; \mathrm{p}<0.05)$. All ewes had been grazed on a ryegrass-white clover herbage with post-grazing herbage masses of less than 1,000 kg DM/ha from breeding until P85 as part of a larger commercial flock. At P85 ewes were transferred to the research site.

On P88, ewes were given an anthelmintic (Bionic Capsule, Merial/Ancare NZ Ltd, Auckland, New Zealand, which releases albendazole and abamectin over 100 days) and were subsequently managed with a target post-grazing herbage masses of less than 1,000 kg DM/ha until P128. At $\mathrm{P} 128$, ewes were allocated to either a 'Control' or 'Ad libitum' ('Adlib') nutritional regimen for the following 14 days (P128 to P142). Each nutritional regimen included ewes randomly allocated from each of the three BCS groups; BCS2.0 (Control $\mathrm{n}=33$, Adlib $\mathrm{n}=34$ ), BCS2.5 (Control $\mathrm{n}=34$, Adlib $\mathrm{n}=33$ ) or BCS3.0 (Control $\mathrm{n}=33$, Adlib $\mathrm{n}=33$ ). The live weights of the ewes allocated to each nutritional regimen did not differ $(p>0.05$; Control $=$ $74.9 \pm 0.7 \mathrm{~kg}$ and Adlib $=74.7 \pm 0.7 \mathrm{~kg}$ ).

The Control nutritional regimen aimed to ensure pregrazing herbage masses of approximately 1,200 kg DM/ha and post-grazing masses of less than 1,000 kg DM/ha. Adlib post grazing covers were managed to ensure herbage covers did not drop below 1,200 kg DM/ha. Previous studies with ryegrass-white clover herbage have indicated that ewe intake is unrestricted when herbage masses are above 1,100 DM/ha (Morris and Kenyon, 2004). Twelve paddocks with a total area of 25.0 ha were used in the current study. At P142, the groups were merged and all ewes were offered ad-libitum feeding conditions until P146. At P146 ewes were randomly allocated to one of seven paddocks for lambing.

Twenty four hours after lambing, ewes and their lambs were moved and randomly allocated to one of three postlambing paddocks. During lactation all ewes were offered ryegrass-white clover herbage masses above $1,200 \mathrm{~kg}$ $\mathrm{DM} / \mathrm{ha}$. Ewes lambed over a 21-day period (9 to $29 \mathrm{Sept}$ 2011) and the study was completed on the 13 Dec, 87 days (L87) after the mid-point of lambing (18 Sept). During lactation ewes and their lambs were managed using rotational grazing.

The study was conducted at Massey University's Keeble Farm, $5 \mathrm{~km}$ south of Palmerston North, New Zealand $\left(40^{\circ}\right.$ South, $175^{\circ}$ East) during the period Jul to Dec 2011 with approval from the Massey University Animal Ethics committee.

\section{Animal measurements}

Body condition scores were determined by palpating the lumbar region, specifically on and around the backbone (spinous and transverse processes) in the loin area, immediately behind the last rib and above the kidneys to 
examine the degree of sharpness or roundness (Jefferies 1961; Kenyon et al., 2014, scale 0 to 5.0 including half units). The condition scores of ewes were recorded at P95, P128, P142, and L87 by a single experienced operator. Live weights of ewes were recorded within one hour of removal from pasture (unfasted) at P95, P128, P142, and L87. Back fat depth of ewes was measured over the 12th rib $(110 \mathrm{~mm}$ from the mid-line) using ultrasound on P95, P127, and P142. At P90, an additional ultrasound pregnancy diagnosis was undertaken to confirm that twin fetuses were carried.

During the lambing period all lambs were tagged, identified to their dam and their sex, birth weight and birthrank were recorded within $12 \mathrm{~h}$ of birth regardless of whether the lamb was dead or alive at the time of tagging. Lamb live weights were also recorded at L31 and L87. Presence of a lamb at L87 was used as a proxy for survival to weaning.

A random cohort of 362 lambs from live twin litters (BCS2.0 [Control $\mathrm{n}=62$, Adlib $\mathrm{n}=56$ ], BCS2.5 [Control $\mathrm{n}$ $=62$, Adlib $n=60$ ] or BCS3.0 [Control $n=60$, Adlib $n=$ 62]) were blood sampled at 24 to 36 hours of age by jugular venipuncture (Becton Dickinson Vacutainer Systems, Franklin Lakes, NJ, USA). Post collection, blood samples were placed on ice before centrifugation at $1,000 \mathrm{~g}$ for 15 min. The serum samples were frozen at $-20^{\circ} \mathrm{C}$ until analysed for indices of colostrum uptake. Serum samples were analysed for gamma glutamyl transferase (GGT; Roche Diagnostics, Basel, Switzerland) and glucose (Roche Diagnostics, Basel, Switzerland).

A sub-sample of the lambs that had had a blood sample collected (BCS2.0 [Control $\mathrm{n}=20$, Adlib $\mathrm{n}=20$ ], BCS2.5 [Control $\mathrm{n}=20$, Adlib $\mathrm{n}=20$ ] or BCS3.0 [Control $\mathrm{n}=20$, Adlib $\mathrm{n}=20$ ]) was also subjected to indirect open-circuit calorimetry (McCutcheon et al., 1983; Kerslake et al., 2009). Briefly, the lamb's head was placed in a sealed plastic hood. The lamb was acclimatised to temperatures of $6^{\circ} \mathrm{C}$ to $8^{\circ} \mathrm{C}$ for a total of $12 \mathrm{~min}$. During this time rectal-temperature (using a rectal temperature probe) and oxygen-consumption measurements were taken over three successive 4-min periods to obtain a stabilised metabolic rate to allow the base heat production to be calculated. At the end of 12 minutes, artificially chilled water (to simulate rain $\left[1^{\circ} \mathrm{C}\right]$ ) was applied through sprinklers at a standardised rate of 1.08 $\mathrm{L} / \mathrm{min}$. In addition, cooled air $\left(5^{\circ} \mathrm{C}\right)$ was passed over the lamb by a fan positioned behind the animal at a speed of 1.0 $\mathrm{m} / \mathrm{s}$. After 20 minutes, the speed of the cooled air was increased to a speed of $1.5 \mathrm{~m} / \mathrm{s}$, and after another 20 minutes, to $2.0 \mathrm{~m} / \mathrm{s}$. The rate then remained constant for the remaining period of time. Rectal-temperature and oxygen consumption measurements were taken at 4-min intervals for $88 \mathrm{~min}$, or until the lamb reached maximal heat production, which ever occurred first. Maximal heat production (summit metabolism) was assumed to have been met when the rectal temperature of the lamb declined at the rate of $1^{\circ} \mathrm{C} / 20 \mathrm{~min}$ and there was no further increase in the consumption rate of oxygen (Alexander, 1962). To facilitate heat loss and to encourage heat production to reach a maximum, all lambs with a birth weight above $4 \mathrm{~kg}$ had the wool clipped from their back and sides leaving a wool depth of $3 \mathrm{~mm}$ (Kerslake et al., 2010). Maximal heat production was calculated from oxygen consumption using the following formula (Revell et al., 2002):

$$
\begin{aligned}
& \text { Maximal heat production }(\mathrm{W}) \\
& =(\text { oxygen consumption per hour } \times 20.46) / 3.6
\end{aligned}
$$

\section{Herbage mass and quality measures}

Ewes were moved to a new paddock as required to ensure the grazed herbage masses were within the desired pre- and post-grazing targets. Each time ewes were moved during the period between P85 and P142 and between P143 and P146 pre- and post-grazing herbage masses were recorded. Herbage mass was also determined immediately prior to the beginning of lambing (P146) and at weekly intervals during lactation. Herbage mass was recorded using a rising plate meter (Ashgrove Pastoral Products, Hamilton, New Zealand, 50 readings per paddock) with a standard calibration (Herbage mass $=$ [158 $\times$ average meter reading $]+$ 200; Hodgson et al., 1999).

Pre-grazing pasture grab samples, representative of the sward the ewes were consuming, were collected prior to the implementation of the nutritional regimen (P97, P111, P118, and P126), during the nutritional regimen (P132, P138, and P147) and during lactation (L18, L32, L47, L68, and L81). The samples were frozen at $-20^{\circ} \mathrm{C}$ until being analysed by near infrared reflectance (NIR) to determine metabolisable energy (ME). A Bruker multi purpose analyser NIR spectrophotometer was used to scan the samples and the resulting NIR spectra were analysed using Optic user software version 5.0 (Ettlingen, Germany).

\section{Statistical analysis}

All statistical analyses were conducted using the statistical software SAS Institute Inc (2010). The mean ME and standard error of the pasture grab samples collected in the pre-nutritional regimen (P85 to P128) and lactation periods (L1 to 87) were calculated. The ME of the herbage samples collected during the nutritional regimen period (P128 to P142) were analysed using a mixed model with the fixed effect of nutritional regimen.

Complete ewe and lamb data were collected from 181 twin-bearing ewes $($ BCS2.0 Control $n=31$, Adlib $n=28$ : BCS2.5 Control $n=31$, Adlib $n=30:$ BCS3.0 Control $n=$ 30 , Adlib $\mathrm{n}=31$ ) of the original 200 ewes. The noninclusion of data from the remaining 19 ewes was because 2 ewes gave birth to a single lamb (BCS2.0 Control $n=1$ and 
BCS2.5 Adlib $n=1), 7$ ewes were removed from study due to either ill health or death $(\mathrm{BCS} 2.0$ Adlib $\mathrm{n}=4$, BCS2.5 Control $\mathrm{n}=2$ and BCS3.0 Adlib $\mathrm{n}=1$ ) and incomplete ewelamb data were collected from 10 ewes (BCS2.0 Control $n$ $=1$, Adlib $\mathrm{n}=2$; BCS2.5 Control $\mathrm{n}=1$, Adlib $\mathrm{n}=2$; BCS3.0 Control $\mathrm{n}=3$, Adlib $\mathrm{n}=1$ ).

Ewe live weight, BCS and back fat depth in pregnancy were analysed using mixed models for repeated measures. The models used included date of lambing as a covariate and fixed effects of nutritional regimen, BCS group and day of pregnancy and their three-way interactions. Models of ewe live weight and BCS at L87 were analysed using mixed models and included date of lambing as a covariate and nutritional regimen, BCS group and the ewe's rearing rank (or where appropriate the rearing rank of the lamb) as fixed effects. The birth weight of lambs was analysed using a mixed model that included the fixed effects of nutritional regimen, BCS group and their two-way interaction. The model also included the sex of lamb as a fixed effect, ewe as a random variable and date of birth as a covariate.

Live weights of lambs at L31 and L87 were analysed using a mixed model that included the fixed effects of nutritional regimen, BCS group and lamb rearing rank and their two-way and three-way interactions. Models included sex of the lamb, lambing paddock and lactation group as fixed effects and date of birth as a covariate. All two-way interactions involving rearing rank were removed from the model, because they were not significant $(p>0.05)$. Repeated measures analysis for lamb live weight was not undertaken because not all lambs were present at every weighing (i.e. there were losses due to death) between birth and weaning.

The GGT data were not normally distributed therefore a square root transformation was used to normalise the distribution. The transformed GGT concentration was analysed using a mixed model that included the fixed effects of nutritional regimen and BCS group and their twoway interaction. The models also included the sex of lamb and lambing paddock as fixed effects and date of birth as a covariate and ewe as a random effect.

The distribution of the glucose concentration of lambs could not be normalised using mathematical transformations. Therefore, glucose concentrations were analysed using the non-parametric Kruskal-Wallis test which contained the fixed effect of either nutritional regimen or BCS. The Kruskal-Wallis test is limited to the analysis of a single fixed effect, therefore, ewe BCS and nutrition were tested separately and no interactions could be tested.

The summit metabolic rate of lambs was analysed using a mixed model that included the fixed effects of nutritional regimen, BCS group and their two-way interaction. The model also included the sex of lamb as a fixed effect, ewe as a random variable and date of birth as a covariate.

The total litter weight for each ewe at L87 (combined live weight of all lambs alive, plus a nominal value of $0 \mathrm{~kg}$ for lambs which were not present) was analysed using a mixed model that included the fixed effects of nutritional regimen and BCS and their two-way interaction. Lambing paddock was used as an additional fixed effect and date of birth as a covariate.

Survival of lambs to L87 was analysed as a binomial trait (alive vs dead) using a generalised model for categorical data modelling (GENMOD) and a logit transformation. The model included the fixed effect of sex of the lamb and the nutritional regimen and BCS group of the dam and their interaction. In addition, the model contained the date of birth of the lamb as a covariate.

The study design tested for the potential interaction between nutritional regimen and BCS. Therefore, in all models, even if this two-way interaction was nonsignificant $(p>0.05)$ the interaction was maintained to allow for testing of the study design and in all tables the data for the interaction are presented.

\section{RESULTS}

\section{Herbage mass}

The pre- and post-grazing herbage masses between P85 and P128 (the pre-nutritional regimen period) were $1,080 \pm 22$ and $795 \pm 24 \mathrm{~kg} \mathrm{DM} / \mathrm{ha}$, respectively. During the period that the nutritional regimens were imposed (P128 to $\mathrm{P} 142$ ), the pre- and post-grazing herbage masses of the Control regimen were lower than the Adlib regimen (Table $1, \mathrm{p}<0.05)$. Mean herbage mass during the lambing period was $1,928 \pm 50 \mathrm{~kg} \mathrm{DM} / \mathrm{ha}$ and throughout lactation was $1,410 \pm 31 \mathrm{~kg} \mathrm{DM} / \mathrm{ha}$.

\section{Herbage metabolisable energy content}

The metabolisable energy content of the herbage offered during the period that the nutritional regimes were imposed did not differ between the nutritional regimens (Table 1, $\mathrm{p}>0.05$ ). During lactation the metabolisable energy of the pasture offered was $12.9 \pm 0.01 \mathrm{MJME} / \mathrm{kg} \mathrm{DM}$.

Table 1. Pre- and post-grazing herbage masses (kg DM/ha) and metabolisable energy content of pastures offered to ewes in the Control and Adlib treatments during the nutritional period (P128 to P142)

\begin{tabular}{lccc}
\hline $\begin{array}{l}\text { Nutritional } \\
\text { regime }\end{array}$ & \multicolumn{2}{l}{ Herbage masses (kg DM/ha) } & $\begin{array}{c}\text { Metabolisable energy } \\
\text { (MJ ME/kg) }\end{array}$ \\
\cline { 2 - 3 } & Pre-grazing & Post-grazing & $13.0 \pm 0.01$ \\
Control & $1,070 \pm 69^{\mathrm{a}}$ & $801 \pm 30^{\mathrm{a}}$ & $13.0 \pm 0.01$ \\
Adlib & $1,784 \pm 69^{\mathrm{b}}$ & $1,333 \pm 33^{\mathrm{b}}$ & $13.0 \pm 0$
\end{tabular}

DM, dry matter; Adlib, ad libitum; ME, metabolisable energy.

${ }^{a b}$ Means within treatments and columns with different superscript letters differ significantly $(p>0.05)$. The absence of superscripts indicate that $\mathrm{p}>0.05$. 


\section{Ewe live weight}

There was no effect of nutritional regimen on ewe live weight either, prior to the start (P128), or at the completion (P142) of the nutrition regimen ( $p>0.05$; Table 2). At both P128 and P142, the live weight of ewes in the BCS2.0 group was lower than in either BCS2.5 or BCS3.0 ( $<<0.05)$, however, BCS2.5 and 3.0 did not differ $(p>0.05)$. There was no interaction between nutritional regimen and ewe BCS group for ewe live weight during pregnancy ( $\mathrm{p}>0.05)$.

At weaning (L87), there was no effect of ewe nutritional regimen on live weight (Control $=77.9 \pm 2.5$ vs Adlib $76.8 \pm 0.24 \mathrm{~kg} ; \mathrm{p}>0.05)$. However, an effect of ewe BCS group was observed whereby ewes in the BCS2.0 were lighter than ewes both in the BCS2.5 and BCS3.0 groups (74.3 \pm 2.6 vs $78.6 \pm 2.4$ vs $79.0 \pm 2.6 \mathrm{~kg}$, respectively; $\mathrm{p}<0.05$ ). There was no interaction between nutritional regimen and ewe BCS group $(\mathrm{p}>0.05)$.

\section{Ewe body condition score}

Ewe nutrition regimen had no effect on ewe BCS at either P128 or P142 ( $>0.05$; Table 2). The BCS of ewes, at both P128 and P142, was lower for BCS2.0 than BCS2.5 groups ewes, which in turn were lower than BCS3.0 $(\mathrm{p}<0.05)$. There was no interaction between nutritional regimen and ewe BCS group $(\mathrm{p}>0.05)$.

The BCS of ewes at weaning (L87) showed that BCS2.0 group ewes had lower condition scores than both BCS2.5 and BCS3.0 group ewes $(\mathrm{BCS} 2.0=2.4 \pm 0.2, \mathrm{BCS} 2.5=$ $2.6 \pm 0.2$, BCS3 $.0=2.7 \pm 0.2 ; \mathrm{p}<0.05)$ but there was no effect of nutritional regimen (Control $=2.5 \pm 0.2$ vs Adlib $=$ $2.5 \pm 0.1 ; \mathrm{p}>0.05)$. There was no interaction between nutritional regimen and ewe BCS group (data not shown; $\mathrm{p}>0.05)$.

\section{Ewe back fat depth}

The back fat depth of ewes at P127 and P141 reflected observations for BCS. Fat depths varied among ewes in each BCS group $(p<0.05$; Table 2$)$ but not between nutritional regimens $(p>0.05)$ nor was there an interaction between BCS and nutritional regimen ( $p>0.05)$.

\section{Lamb live weight, total litter weight and survival}

At birth, L31 and weaning at L87 there was no effect of ewe BCS, nutritional regimen or their two-way interaction on lamb live weight ( $>>0.05$; Table 3 ). Lamb rearing rank, however, had an effect on lamb live weight at L31 and L87 whereby singleton-reared lambs were heavier than twinreared lambs $(p<0.05)$. Lamb survival to weaning did not differ between ewe BCS or nutritional regimen, however, their interaction tended towards significance $(\mathrm{p}=0.07$, Table 4). Lambs born to Control BCS2.5 ewes had lower survival rates than Control BCS3.0 ewes $(\mathrm{p}<0.05)$ and tended to have lower survival rates than lambs born to Adlib BCS2.5 ewes ( $p=0.06$, Table 4). The total litter live weight weaned per ewe did not vary between ewe BCS, nutritional regimen or their interaction ( $p>0.05$; Table 4$)$.

\section{Indices of colostrum uptake}

Serum GGT concentration of lambs born to BCS3.0 ewes was greater than for lambs born to BCS2.0 ewes and BCS2.5 ewes $(51.8 \pm 1.9$ vs $46.5 \pm 1.9$ and $45.6 \pm 1.9 \mathrm{IU} / \mathrm{mL}$, respectively; $\mathrm{p}<0.05)$. There was, however, no effect of ewe nutrition nor was there an interaction between BCS and nutrition on lamb serum GGT (data not shown, $\mathrm{p}>0.05$ ). In

Table 2. The effect of ewe condition score group (CS2.0 vs CS2.5 vs CS3.0) and nutritional regimen in late-pregnancy (Control vs Adlib) on mean $( \pm$ SE) ewe condition score at P128 and P142, ewe live weight $(\mathrm{kg})$ and ewe back fat depth (mm) at P127 and P141

\begin{tabular}{|c|c|c|c|c|c|c|c|}
\hline & \multirow{2}{*}{$n$} & \multicolumn{2}{|c|}{ Body condition score } & \multicolumn{2}{|c|}{ Live weight (kg) } & \multicolumn{2}{|c|}{ Back fat depth (mm) } \\
\hline & & P128 & P142 & P128 & P142 & P127 & P141 \\
\hline \multicolumn{8}{|l|}{ Condition group } \\
\hline CS2.0 & 59 & $2.1 \pm 0.06^{\mathrm{a}}$ & $2.2 \pm 0.06^{\mathrm{a}}$ & $76.2 \pm 0.87^{\mathrm{a}}$ & $82.6 \pm 0.95^{\mathrm{a}}$ & $6.2 \pm 0.22^{\mathrm{a}}$ & $5.9 \pm 0.21^{\mathrm{a}}$ \\
\hline $\mathrm{CS} 2.5$ & 61 & $2.5 \pm 0.06^{\mathrm{b}}$ & $2.6 \pm 0.06^{\mathrm{b}}$ & $79.4 \pm 0.85^{\mathrm{b}}$ & $86.0 \pm 0.93^{\mathrm{b}}$ & $7.5 \pm 0.22^{\mathrm{b}}$ & $7.2 \pm 0.21^{\mathrm{b}}$ \\
\hline CS3.0 & 61 & $2.7 \pm 0.06^{\mathrm{c}}$ & $2.8 \pm 0.06^{\mathrm{c}}$ & $81.2 \pm 0.85^{\mathrm{b}}$ & $87.0 \pm 0.93^{b}$ & $8.4 \pm 0.22^{\mathrm{c}}$ & $8.0 \pm .20^{\mathrm{c}}$ \\
\hline \multicolumn{8}{|l|}{ Nutritional regimen } \\
\hline Control & 89 & $2.5 \pm 0.05$ & $2.5 \pm 0.05$ & $79.0 \pm 0.69$ & $85.1 \pm 0.76$ & $7.2 \pm 0.18$ & $7.1 \pm 0.16$ \\
\hline Adlib & 92 & $2.4 \pm 0.05$ & $2.6 \pm 0.05$ & $79.1 \pm 0.71$ & $85.3 \pm 0.77$ & $7.5 \pm 0.18$ & $7.0 \pm 0.17$ \\
\hline \multicolumn{8}{|c|}{ Condition group $\times$ nutritional regimen ${ }^{1}$} \\
\hline CS2.0×Control & 31 & $2.2 \pm 0.08^{\mathrm{a}}$ & $2.3 \pm 0.08^{\mathrm{a}}$ & $75.8 \pm 1.20^{\mathrm{a}}$ & $81.7 \pm 1.30^{\mathrm{a}}$ & $6.2 \pm 0.30^{\mathrm{a}}$ & $5.9 \pm 0.28^{\mathrm{a}}$ \\
\hline CS2.0×Adlib & 28 & $2.1 \pm 0.08^{\mathrm{a}}$ & $2.2 \pm 0.08^{\mathrm{a}}$ & $76.6 \pm 1.26^{\mathrm{a}}$ & $83.5 \pm 1.37^{\mathrm{ab}}$ & $6.3 \pm 0.31^{\mathrm{a}}$ & $5.9 \pm 0.30^{\mathrm{a}}$ \\
\hline CS2.5×Control & 31 & $2.4 \pm 0.08^{\mathrm{b}}$ & $2.5 \pm 0.08^{\mathrm{b}}$ & $80.4 \pm 1.20^{\mathrm{b}}$ & $86.3 \pm 1.31^{\mathrm{b}}$ & $7.5 \pm 0.30^{\mathrm{b}}$ & $7.4 \pm 0.28^{\mathrm{b}}$ \\
\hline CS2.5×Adlib & 30 & $2.5 \pm 0.08^{\mathrm{bc}}$ & $2.7 \pm 0.08^{\mathrm{bc}}$ & $79.1 \pm 1.22^{\mathrm{ab}}$ & $85.8 \pm 1.33^{\mathrm{bc}}$ & $7.6 \pm 0.31^{\mathrm{bc}}$ & $7.1 \pm 0.29^{\mathrm{b}}$ \\
\hline CS3.0×Control & 30 & $2.7 \pm 0.08^{\mathrm{cd}}$ & $2.8 \pm 0.08^{\mathrm{c}}$ & $80.7 \pm 1.22^{\mathrm{b}}$ & $87.4 \pm 1.33^{\mathrm{c}}$ & $8.0 \pm 0.31^{\mathrm{cd}}$ & $7.9 \pm 0.29^{\mathrm{bc}}$ \\
\hline CS3.0×Adlib & 31 & $2.7 \pm 0.08^{\mathrm{d}}$ & $2.7 \pm 0.08^{\mathrm{c}}$ & $81.8 \pm 1.20^{\mathrm{b}}$ & $86.5 \pm 1.30^{\mathrm{bc}}$ & $8.8 \pm 0.30^{\mathrm{d}}$ & $8.2 \pm 0.29^{c}$ \\
\hline
\end{tabular}


Table 3. The effect of ewe condition score group (CS2.0 vs CS2.5 vs CS3.0), rearing rank (twin-singleton or twin-twin) and nutritional regimen in late-pregnancy (Control vs Adlib) on mean $( \pm \mathrm{SE})$ lamb live weight $(\mathrm{kg})$ at birth, $\mathrm{L} 31$ and $\mathrm{L} 87$

\begin{tabular}{|c|c|c|c|c|c|c|}
\hline & \multicolumn{6}{|c|}{ Lamb live weight $(\mathrm{kg})$} \\
\hline & $n$ & Birth & $n$ & L31 & $n$ & L87 \\
\hline \multicolumn{7}{|l|}{ Condition group } \\
\hline CS2.0 & 103 & $5.1 \pm 0.26$ & 102 & $10.4 \pm 0.32$ & 103 & $29.4 \pm 0.86$ \\
\hline CS2.5 & 108 & $5.1 \pm 0.25$ & 105 & $10.5 \pm 0.34$ & 108 & $29.6 \pm 0.92$ \\
\hline CS3.0 & 106 & $5.0 \pm 0.26$ & 107 & $10.7 \pm 0.35$ & 106 & $29.7 \pm 0.93$ \\
\hline \multicolumn{7}{|l|}{ Nutrition regimen } \\
\hline Control & 161 & $5.1 \pm 0.24$ & 155 & $10.6 \pm 0.33$ & 161 & $29.5 \pm 0.88$ \\
\hline Adlib & 156 & $5.1 \pm 0.25$ & 158 & $10.5 \pm 0.33$ & 156 & $29.6 \pm 0.88$ \\
\hline \multicolumn{7}{|l|}{ Rearing rank } \\
\hline Twin-singleton & - & - & 28 & $10.9^{\mathrm{b}} \pm 0.40$ & 25 & $30.4^{\mathrm{b}} \pm 1.10$ \\
\hline Twin-twin & - & - & 286 & $10.2^{\mathrm{a}} \pm 0.30$ & 292 & $28.3^{\mathrm{a}} \pm 0.75$ \\
\hline \multicolumn{7}{|c|}{ Condition group $\times$ nutrition regimen ${ }^{1}$} \\
\hline CS2.0xControl & 54 & $5.0 \pm 0.27$ & 54 & $10.4 \pm 0.36$ & 54 & $29.1 \pm 0.94$ \\
\hline CS2.0×Adlib & 49 & $5.1 \pm 0.27$ & 48 & $10.5 \pm 0.36$ & 49 & $29.7 \pm 0.96$ \\
\hline CS2.5×Control & 57 & $5.3 \pm 0.25$ & 55 & $10.6 \pm 0.37$ & 57 & $29.1 \pm 0.98$ \\
\hline CS2.5×Adlib & 51 & $5.0 \pm 0.27$ & 49 & $10.5 \pm 0.39$ & 51 & $30.1 \pm 1.02$ \\
\hline CS3.0 $\times$ Control & 50 & $5.0 \pm 0.27$ & 49 & $10.8 \pm 0.39$ & 50 & $30.4 \pm 1.03$ \\
\hline CS3.0×Adlib & 56 & $5.1 \pm 0.27$ & 58 & $10.5 \pm 0.38$ & 56 & $29.1 \pm 0.99$ \\
\hline
\end{tabular}

Adlib, ad libitum; SE, standard error.

${ }^{\mathrm{ab}}$ Means within treatments and columns with different superscript letters differ significantly $(\mathrm{p}<0.05)$. The absence of superscripts indicate that $\mathrm{p}>0.05$

${ }^{1}$ Ewe body condition score group by nutrition regimen interaction.

addition, lamb serum glucose concentration did not differ between ewe BCS or nutritional regimens (data not shown, $\mathrm{p}>0.05)$.

\section{Lamb summit metabolic rate}

The summit metabolic rate of lambs born to BCS2.0, BCS2.5, and BCS3.0 ewes did not differ and were 17.5 \pm 0.6 ,
$17.7 \pm 0.6$, and $17.3 \pm 0.5 \mathrm{~W} / \mathrm{kg}^{0.75}$, respectively $(\mathrm{p}>0.05)$. The summit metabolic rate of lambs born to ewes in the Control and Adlib groups also did not differ $(\mathrm{p}>0.05 ; 17.2 \pm 0.2$ and $17.8 \pm 0.5$, respectively). There was no interaction between ewe BCS and nutrition on lamb summit metabolic rate $(\mathrm{p}>0.05)$.

Table 4. The effect of ewe condition score group (CS $\leq 2.0$ vs $\mathrm{CS} 2.5$ vs $\mathrm{CS} \geq 3.0$ ) and nutritional regimen in late-pregnancy (Control vs Adlib) on lamb survival (mean logit value \pm SE and back transformed $\%$ in parenthesis) and total litter live weight of lamb (mean \pm SE) weaned per ewe $(\mathrm{kg})$

\begin{tabular}{|c|c|c|c|c|}
\hline & $n^{1}$ & Lamb survival $(\%)^{2}$ & $n$ & Total litter live weight $(\mathrm{kg})^{3}$ \\
\hline \multicolumn{5}{|l|}{ Condition group } \\
\hline CS2.0 & 118 & $1.99 \pm 0.283(88.0)^{3}$ & 59 & $51.3 \pm 2.37$ \\
\hline $\mathrm{CS} 2.5$ & 122 & $2.41 \pm 0.354(91.8)$ & 61 & $52.7 \pm 2.35$ \\
\hline CS3.0 & 122 & $1.93 \pm 0.279(87.3)$ & 61 & $51.3 \pm 2.32$ \\
\hline \multicolumn{5}{|l|}{ Nutritional regimen } \\
\hline Control & 178 & $2.18 \pm 0.266(90.0)$ & 89 & $51.9 \pm 2.03$ \\
\hline Adlib & 184 & $2.02 \pm 0.237(88.3)$ & 92 & $51.6 \pm 1.99$ \\
\hline \multicolumn{5}{|c|}{ Condition group $\times$ nutritional regimen ${ }^{4}$} \\
\hline CS2. $0 \times$ Control & 62 & $1.94 \pm 0.383^{\mathrm{ab}}(87.4)$ & 31 & $51.6 \pm 3.26$ \\
\hline CS2.0×Adlib & 56 & $2.05 \pm 0.412^{\mathrm{ab}}(88.6)$ & 28 & $50.9 \pm 3.19$ \\
\hline CS2.5×Control & 62 & $3.06 \pm 0.601^{\mathrm{ab}}(95.5)$ & 31 & $53.8 \pm 3.13$ \\
\hline CS2.5×Adlib & 60 & $1.76 \pm 0.368^{\mathrm{ab}}(85.3)$ & 30 & $51.6 \pm 3.27$ \\
\hline CS3.0×Control & 60 & $1.60 \pm 0.350^{\mathrm{a}}(83.1)$ & 30 & $50.1 \pm 3.16$ \\
\hline CS3.0×Adlib & 62 & $2.26 \pm 0.433^{\mathrm{b}}(90.1)$ & 31 & $52.5 \pm 3.31$ \\
\hline
\end{tabular}

Adlib, ad libitum; SE, standard error.

${ }^{1}$ Number of lambs born. ${ }^{2}$ Logit value and back transformed percentage in brackets. ${ }^{3}$ Total litter weight of lambs per ewe at L87.

${ }^{4}$ Ewe body condition score group by nutritional regimen interaction.

${ }^{\mathrm{abc}}$ Means within treatments and columns with different superscript letters differ significantly $(\mathrm{p}<0.05)$. The absence of superscripts indicate that $\mathrm{p}>0.05$. 


\section{DISCUSSION}

The present study aimed to determine the impact of offering twin-bearing ewes controlled (restricted) nutritional conditions from day 128 until day 142 of pregnancy in comparison to ad libitum. Previous studies have indicated that ryegrass-white clover herbage mass above $1,100 \mathrm{~kg} \mathrm{DM} / \mathrm{ha}$ results in ewe intake being unrestricted (Morris et al., 1993a; Morris and Kenyon, 2004). Further, herbage mass of approximately $800 \mathrm{~kg}$ $\mathrm{DM} / \mathrm{ha}$ at day 123 of pregnancy resulted in ewe intakes that were less than $60 \%$ of that achieved by ewes on approximately 1,200 kg DM/ha (Morris and Kenyon, 2004). Therefore, the grazing conditions recorded during the present study suggest that the Control group ewes were offered restricted grazing conditions compared with the adlib group ewes. These nutritional regimens, however, had no effect on the ewe live weight, BCS and back fat data at the end of the 14-day nutritional regimen period. The cause of this lack of difference is unknown, but may be a result of the decrease in rumen volume as previously reported in late pregnancy (Forbes, 1968; Everts, 1990) thus reducing ewe intakes for both nutritional regimens. Kenyon et al. (2013), however, reported that triplet-bearing ewes, when offered similar pre- and post-grazing masses over the same time period to the present study, showed differences in ewe live weight, BCS and back fat depth. In the present study, given the lack of differences in ewe parameters measured in late pregnancy, it is unsurprising that lamb live weights, indices of colostrum intake, heat production and survival to weaning were unaffected by ewe nutritional regimens. The lack of observed effects present in the offspring matches that of Kenyon et al. (2013) who reported that, using similar nutritional regimens, there were no effects on triplet lamb live weight, indices of colostrum uptake or survival to weaning. Combined these studies and those of earlier studies (Morris and Kenyon, 2004; Corner et al., 2008; Kenyon et al., 2011; Kenyon et al., 2012a) indicate that multiple bearing ewes can be managed under pre- and postgrazing ryegrass-white clover herbage masses of approximately 1,200 and $800 \mathrm{~kg} \mathrm{DM} / \mathrm{ha}$ respectively from mid- to late-pregnancy without detrimentally affecting lamb performance to weaning, when the ewes are subsequently offered ad libitum grazing conditions in lactation. This restricted nutritional regimen would allow farmers to conserve additional herbage for the lactation period.

The present study utilised lamb GGT concentration at 24 to 36 hours of age as an indicator of colostrum intake and glucose as an indicator of the lambs nutritional state (Mellor, 1987; Tessman et al., 1997; Maden et al., 2003). Ewe BCS affected lamb GGT but not glucose concentrations with lambs born to ewes with BCS of three having greater GGT concentrations than lambs born to ewes with lower BCSs. This indicates that these lambs consumed additional colostrum but that their overall nutritional state did not differ. Al-Sabbagh (2009) reported that ewes with a $\mathrm{BCS}$ in the range of 2.5 to 3.5 tended to produce more colostrum than ewes of worse condition. However, others have reported no effect of ewe BCS on either colostrum IgG concentration (Al-Sabbagh et al., 1995; Rozeboom et al., 2007) or apparent colostrum intake of lambs (Kenyon et al., 2012ab; 2013). Given the lack of consistent effects in the literature, and that in the present study both lamb glucose concentrations in early life and survival to weaning were not affected by ewe BCS, it is unlikely that over the range of BCSs tested, body condition scoring could be used as a tool to improve lamb colostrum intake and survival.

A positive effect of ewe BCS on lamb live weight at both birth and weaning and on lamb growth to weaning has previously been reported (Hossamo et al., 1986; EverettHincks and Dodds, 2009; Thompson et al., 2011). In addition, ewe body condition in late pregnancy has been reported to affect milk production (Gibb and Treacher, 1980; Hossamo et al., 1986). In the present study, however, no effect of ewe BCS on the live weight of lambs was observed. It is possible that the herbage conditions during lactation did not result in ewes having to draw on body reserves to ensure high levels of milk production. Gibb and Treacher (1980) reported that under conditions in which ewes lost live weight during lactation, those of higher body condition tended to produce more milk, while under conditions where ewes had access to adequate herbage, body condition had no impact on milk production. Other studies have also reported no effect of ewe BCS on lamb growth and live weight to weaning (Gibb and Treacher, 1982; Al-sabbagh et al., 1995; Aliyari et al., 2012).

Ewe BCS had no effect on lamb summit heat production. This appears to be the first study examining this relationship. Therefore, while the results indicate no relationship further studies might wish to consider a greater range of ewe nutritional treatments and BCSs in lactation before firm conclusions can be drawn.

In the present study, no interactions between ewe nutritional regimen and BCS for any of the lamb traits measured were observed. This indicates that there was no advantage of a greater condition score in the controlled nutritional regimen, which does not support the hypothesis proposed. However, it is possible that the ewe BCSs tested in this study were not extreme enough for an effect to be observed. The ewe BCS of 2.0 and 3.0 in late pregnancy were only associated with a $2 \mathrm{~mm}$ difference in back fat depth. Further studies should consider utilising ewes of body condition below and above 2.0 and 3.0, respectively. It is of interest to note that ewes from the condition score 2.0 group also had lower BCSs at weaning compared with the other condition score groups. Ewe reproductive 
performance is known to be affected by body condition (see review by Kenyon et al., 2014), therefore, the body condition group 2.0 ewes are more likely to have a negative carry-over affect in the following year's reproductive performance unless provided preferential feeding post weaning. Further, the general absence of an interaction between nutritional regimens and BCS groups may have been due to the nutritional conditions present in lactation. Additional studies may wish to examine this relationship under conditions in which ewe nutrition in lactation are below optimal.

\section{CONCLUSION}

In late-pregnancy pre- and post-grazing herbage masses of approximately 1,100 and $800 \mathrm{~kg} \mathrm{DM} /$ ha respectively did not negatively impact the performance of twin-bearing ewes or their lambs in lactation compared with ewes offered ad libitum feeding conditions. Therefore, if the supply of pasture is limited farmers may provide these lower levels of nutrition to their twin-bearing ewes and achieve a similar performance as those offered ad libitum fed, if they can subsequently offer unrestricted conditions in lactation. These results also indicate that under the herbage conditions of the present study, there was little difference in ewe and lamb performance over the BCS range of 2.0 to 3.0. Therefore, ewes with condition scores between 2.0 and 3.0 do not need to be managed separately.

\section{ACKNOWLEDGMENTS}

The authors wish to acknowledge Mr Dean Burnham and $\mathrm{Mr}$ Geoff Purchas for their technical assistance provided and Beef+Lamb New Zealand and Massey University for funding this study and Gravida for part funding P.R. Kenyon.

\section{REFERENCES}

Alexander, G. 1962. Temperature regulation in the new-born lamb. IV. The effect of wind and evaporation of water from the coat on metabolic rate and body temperature. Aust. J. Agric. Res. 13:82-99.

Aliyari, D., M. M. Moeini, M. H. Shahir, and M. A. Sirijani. 2012. Effect of body condition score, live weight and age on reproductive performance of Afshari ewes. Asian J. Anim. Vet. Adv. 7:904-909.

Al-Sabbagh, T. A., L. V. Swanson, and J. M. Thompson. 1995. The effect of ewe body condition at lambing on colostral immunoglobulin $\mathrm{G}$ concentration and lamb performance. J. Anim. Sci. 73:2860-2864.

Al-Sabbagh, T. 2009. Colostral immunoglobulin as affected by nutritional status in Border Leicester Merino ewes deliver at Kuwait. Global Vet. 3:281-285.

Corner, R. A., P. R. Kenyon, K. J. Stafford, D. M. West, N. Lopez-
Villalobos, S. T. Morris, and M. H. Oliver. 2008. Effect of nutrition from mid to late pregnancy on the performance of twin- and triplet-bearing ewes and their lambs. Aust. J. Exp. Agric. 48:666-671.

Everts H. 1990. Feeding strategy during pregnancy for ewes with a large litter size. 1. Effect of quantity and composition of concentrates on intake and reproductive performance. Netherlands. J. Agric. Sci. 38:527-540.

Everett-Hincks, J. M. and K. G. Dodds. 2009. Management of maternal-offspring behavior to improve lamb survival in easy care sheep systems. J. Anim. Sci. 86:E259-270.

Forbes, J. M. 1968. The physical relationships of the abdominal organs in the pregnant ewe. J. Agric. Sci. 70:171-177.

Gibb, M. J. and T. T. Treacher. 1980. The effect of ewe body condition at lambing on the performance of ewes and their lambs at pasture. J. Agric. Sci. 95:631-640.

Gibb, M. J. and T. T. Treacher. 1982. The effect of body condition and nutrition during late pregnancy on the performance of grazing ewes during lactation. Anim. Prod. 34:123-129.

Hodgson, J., P. N. P. Matthews, C. Matthew, and R. J. Lucas. 1999. Pasture measurement. In: New Zealand Pasture and crop science (Eds. J. White and J. Hodgson). Oxford University Press, Auckland, New Zealand. pp. 59-66.

Hossamo, H. E., J. B. Owen, and M. F. A. Farid. 1986. Body condition score and production in fat-tailed Awassi sheep under range conditions. Res. Dev. Agric. 3:99-104.

Jefferies, B. C. 1961. Body condition scoring and its use in management. Tas. J. Agric. 32:19-21.

Kenyon, P. R., S. K. Maloney, and D. Blache. 2014. Review of sheep body condition in relation to production characteristics. N.Z. J. Agric. Res. 57:38-64.

Kenyon, P. R., S. T. Morris, R. E. Hickson, P. J. Back, A. L. Ridler, K. J. Stafford, and D. M. West. 2013. The effects of body condition score and nutrition of triplet-bearing ewes in late pregnancy. Small Rumin. Res. 113:154-161.

Kenyon, P. R., R. E. Hickson, P. G. Hutton, S. T. Morris, K. J. Stafford, and D. M. West. 2012a. Effect of twin-bearing ewe body condition score and late pregnancy nutrition on lamb performance. Anim. Prod. Sci. 52:483-490.

Kenyon, P. R., S. T. Morris, R. E. Hickson, K. J. Stafford, and D. M. West. 2012b. Nutritional restriction of triplet-bearing ewes and body condition score has minimal impacts. NZ. J. Agric. Res. 55:359-370.

Kenyon, P. R., S. J. Pain, P. G. Hutton, C. M. C. Jenkinson, S. T. Morris, S. W. Peterson, and H. T. Blair. 2011. Effects of twinbearing ewe nutritional treatments on ewe and lamb performance to weaning. Anim. Prod. Sci. 51:406-415.

Kerslake, J. I., P. R. Kenyon, K. J. Stafford, S. T. Morris, and P. C. H. Morel. 2009. The effect of offering concentrate supplement to twin- and triplet-bearing ewes grazing a $60 \mathrm{~mm}$ herbage sward height on lamb birth weight, heat production and postnatal growth. J. Agric. Sci. 147:613-624.

Kerslake, J. I., P. R. Kenyon, K. J. Stafford, S. T. Morris, and P. C. H. Morel. 2010. Can maternal iodine supplementation improve twin- and triplet-born lamb plasma thyroid hormone concentrations and thermoregulation capabilities in the first 24-36 h of life? J. Agric. Sci. 148:453-463.

Kerslake, J. I., P. R. Kenyon, K. J. Stafford, S. T. Morris, and P. C. H. Morel. 2009. The effect of offering concentrate supplement 
to twin- and triplet-bearing ewes grazing a $60 \mathrm{~mm}$ herbage sward height on lamb birth weight, heat production and postnatal growth. J. Agric. Sci. 147:613-624.

McCutcheon, S. N., C. W. Holmes, M. F. McDonald, and A. L. Rae. 1983. Resistance to cold stress in the newborn lamb 1. Responses of Romney, Drysdale $\times$ Romney, and Merino lambs to components of the thermal environment. NZ. J. Agric. Res. 26:169-174.

Maden, M., V. Altunok, F. M. Birdane, V. Aslan, and M. Nizamlioglu. 2003. Blood and colostrum/milk serum gammaglutamyltransferase activity as a predictor of passive transfer status in lambs. J. Vet. Med. B. 50:128-131.

Matthews, P. N. P., J. Hodgson, and J. G. H. White. 2000. Livestock farming systems in New Zealand. In: New Zealand pasture and crop science (Eds. J. G. H. White and J. Hodgson). Oxford University Press, Melbourne, Australia. pp. 133-151.

Mellor, D. J. 1987. Feeding pregnant ewes and newborn lambs during experiment. In: Animal Models in Fetal Medicine VI. (Ed. P. W. Nathanielsz). Perinatology Press, Ithaca, NY, USA. pp. 55-92.

Morris, S. T. and P. R. Kenyon. 2004. The effect of litter size and sward height on ewe and lamb performance. NZ. J. Agric. Res. 47:275-286.

Morris, S. T., W. J. Parker, H. T. Blair, and S. N. McCutcheon. 1993. Effect of sward height during late pregnancy on intake and performance of continuously stocked June- and Augustlambing ewes. Aust. J. Agric. Res. 44:1635-1651.
Nicol, A. M. and I. M. Brookes. 2007. The metabolisable energy requirements of grazing livestock. In: Pasture and supplements for grazing animals (Eds. P. V. Rattray, I. M. Brookes, and A. M. Nicol). Occasional Publication No. 14. New Zealand Society of Animal Production Hamilton, New Zealand. pp. 151-172.

Revell, D. K., S. T. Morris, Y. H. Cottam, J. E. Hanna, D. G. Thomas, S. Brown, and S. N. McCutcheon. 2002. Shearing ewes at mid-pregnancy is associated with changes in fetal growth and development. Aust. J. Agric. Res. 53:697-705.

Rozeboom, K. J., B. D. Neale, and C. S. Darroch. 2007. Relationships among ewe body condition scores, lamb vigour, colostral quality, milk composition and reproductive performance. J. Anim. Sci. 85(Suppl 2):138(Abstr.).

SAS Institute Inc. 2010. SAS User's Guide: Version 9.3. SAS Institute Inc., Cary, NC, USA.

Statistics New Zealand. 2013. http://www.stats.govt.nz/browse_ for_stats/industry_sectors/agriculture-horticulture-forestry.aspx. Accessed: November 8, 2013.

Tessman, R. K., J. W. Tyler, S. M. Parish, D. L. Johnson, R. G. Gant, and H. A. Grasseschi. 1997. Use of age and serum $\gamma$ glutamyltransferase activity to assess passive transfer status in lambs. J. Am. Vet. Med. Assoc. 211:1163-1164.

Thompson, A. N., M. B. Ferguson, A. J. D. Campbell, D. J. Gordon, G. A. Kearney, C. M. Oldham, and B. L. Paganoni. 2011. Improving the nutrition of Merino ewes during pregnancy and lactation increases weaning weight and survival of progeny but does not affect their mature size. Anim. Prod. Sci. 51:784-793. 